\title{
Social mobility in globalization circumstances
}

\author{
Hasan Jashari \\ PhD Candidate, South East European University, Tetova, Macedonia \\ Email: h.jashari@seeu.edu.mk
}

\section{Doi:10.5901/ajis.2015.v4n2s2p150}

\begin{abstract}
In recent years in Macedonia, there has been an accelerated social stratification. The lower stratum population is constantly increasing. Laeken poverty indicators based on the Survey on Income and Living Conditions (2010) the at-risk-of-poverty-rate for unemployed persons is $50.6 \%$, while the at-risk-of-poverty-rate for employed persons is $9.9 \%$. The pluralism of the ' 90 s began with the ideals for equal opportunities but people are now desperate and they are struggling with their own illusions. Despite the fact that many are experiencing vertical mobility, this is more a result of changes in the employment structure rather than the existence of a high level of equal opportunities. On the other hand, globalization is urging geographical mobility at large, and this makes young generations migrate in larger cities and more developed countries. The inequalities between people are becoming more evident especially the new lifestyle of the rich stratum of the society such as politicians, businesspersons, real estate owners and traders. This paper deals with issues that concern movements of entire generations based on their education level and jobs they perform, in externally highly influenced environments. Women in Macedonia are increasingly enrolling at universities and this makes them competent for many professions. However, statistical indicators show that they are not yet present enough in managerial positions in various different institutions or on the highly paid jobs lists. The salary in Macedonia are low. Blau and Duncan (2005) assert the importance of mobility for understanding modern industrial society, particularly its stratified character Through statistical data, we will attempt to prove the above-mentioned approaches.
\end{abstract}

Keywords: Social mobility, Globalization, Living condition, Jobs

\section{Introduction}

This study aims at explaining the phenomenon of changes in social mobility in everyday life conditions in the global society.

We are all aware that industrialism motivated a series of colossal processes in people's social lives; the urbanization of places increased the mobility of the population and its movements towards industrial centers and big cities. The movements of the rural part of the population have been the most emphasized. From the beginning of the $18^{\text {th }}$ century, industries became the moving force of the social progress. It was then that the need for a huge educated workforce emerged, which Marx elaborates as the need of capitalists for increasing the profit and class exploitation. The educated workforce went down even to the workers' children who had at least to be able to read, write and do some basic calculations in order to operate the complicated technical-technological equipments. We can all remember the scenes from the very famous movie of Titanic whereupon the waits for obtaining a ferry ticket lasted for weeks and even months. It was an inrush, a movement, which people were ready to undertake for the sake of a change in their lives; they wanted to climb up, go to the States, which was undergoing an impressive economic and industrial development and get rich. This was the American dream for a better and richer life.

The greatest transformations in the structure of human society would happen in the 1970s when the computer was first introduced in the process of reproduction of material goods in industry as well as in other public services. It was then that the advantage of being well educated over the ownership of lands, properties, physical engagement, came onto surface. This would happen exactly at the time when Daniel Bell would use the word globalization in his writings.

In just a couple of decades, society got restructured, changed its shape and outlook, its ideological and political structure and viewpoint, i.e. its key institutions (Drucker, 1995, pp12). A few decades later, it happened for us to have a new world, whereas human beings being born in recent years were not able to imagine the world in which their parents and their grandparents had been born. They are people with new ideals, with great ambitions. They work using other, more sophisticated work tools, and in general, have jobs that simply did not exist at the time of their grandparents. They keep using new products in their everyday lives, including food, transportation, clothes, healthcare, communication, and leisure activities. 
Karl Marx in his work Manifesto of the Communist Party understands social mobility as a struggle between fundamental social classes; bourgeois and working class. Marx's demand is that workers should join and have massive action "The real outcome of their struggle is not instantaneous but the success of the union of workers who expanded all the more" (Marx, K., 1978, pp 6-7). In such conditions, Marx would naturally, as the wind in the ships sails sees the development of means of communication (transports) and industry which enables the interconnection of employees of different countries and geographies. This struggle of classes represents, according to Marx, a political struggle for the rights of workers and the right place of workers in society; its socio-economic position. (Marx K., Engels,F., 1978 pp 6-7).

However, is everything going really smoothly in the era of neo-liberalism, at a time when the world is being governed by multinational corporations? If we refer to David Held, ( Steger, 2003) according to whom we are living in an optimistic era for our world, when the barriers among nations have been eliminated, economic liberalism is at its best, trade and investments are blossoming, inequalities in incomes among nations are decreasing, and the collection of wealth is reaching high records, then everything looks pink. However, Manfred Steger poses some questions to David Held's claims. He asks, who indeed is 'we'? Who has proved that neo-liberalism is beneficial? The truth, according to Steger, is that goods, innovations, possibilities in globalization, are spread unequally. The power is focused on a small group of selected people, regions and corporations o the account of the majority in the world. This is how some people collect a lot of wealth for themselves, and a lot of others do not.

\section{Methodology}

We have gathered fact graphic materials for the needs of its theoretical and practical analysis. This will enable the attendance and ownership of information on how social stratification in globalization occurs, how people struggle to live and work under new conditions, with lots of possibilities and alternatives yet under the pressure of unprecedented competition. They will either move forward and progress considerably or become social cases to be supported by the state.

We have also gathered information from the observation of various different phenomena, along with statistical data and we have reviewed sufficient references and literature in this quite fluid subject matter related to rapid social changes and stratification. The gathered materials will be analyzed and interpreted.

\section{Literature review}

When we talk about social mobility, we talk about the social dynamics as a very important part of individuals and groups life; we talk about sociology and social changes itself. There is vertical and horizontal mobility. Vertical mobility is the movement of layers for example from the lower ones to those that are higher that is usually followed by the level of education, wealth, jobs, goods, heritage etc. We also have top-down movement that also depends on a large number of factors and is often a regressive process. Horizontal movement is when the person is carried in the same position with symbolic changes without moving the bottom up or vice versa, but rather as spatial movement from one to another profession or in other enterprises. Individual mobility is the position, the inclusion of the individual in a social Grouping or layer which exists or wins a social position. Mobility group is the movement of a group up or down. But we constantly, especially in conditions of globalization have quick movement and changes therefore we also have the mobility between generations. Then we have mobility of occupations, real estate, education, etc.

Two directions or theories are crucial in sociological literature as regards social mobility - the functional theory of social stratification and the theory of conflict. The former defends the thesis that social inequalities exist because society itself benefits from them. All societies prefer the system in which individuals are motivated to take up roles and perform their functions in the society. This theory has been criticized a lot. As regards the theory of conflict, seen from this perspective, the society represents an arena in which people fight for privileges, prestige, power and advantage through coercion (Hughes, J. C. Kroehler, Vander Zanden, J.2003).

Based on comparative studies on mobility, we can conclude that Piterim Sorokin's studies have analyzed the possibilities for faster advancement in the USA. In his opinion, there are a lot more chances of achieving the desired goals there than anywhere else in the world.

In this respect, higher strata have more possibilities and this is in line with the person's social status that climbs up from the bottom. Whereas, Blau and Duncan have concluded that vertical mobility is commonly such and they refer to those who carry out transitions from one position to another close to the former, e.g. from a qualified worker to a highlyqualified worker or a specialist in a working operation. Distant mobility is usually rare, e.g. from a qualified worker to an 
engineer (Giddens, 1997), (Hughes, ET all, 2003)).

On the other hand, mobility among generations has its own peculiarities and specifications. In Turkey, e.g. the exploitation of workers and their children, according to Ali Bullac, is obvious. Society is divided into strata. The owners of the capital are higher classes. "In factories there are workers who are still not called the Proletariat. They reside in cabins, i.e. illegally constructed tiny houses in the suburbs. They have many children. They suffer a lot from illnesses and filth. Their opportunities for education are very limited..." (Bullac, 2005). Even though many things have already changed for better in Turkey, these issues still exist.

Social Darwinism also legitimizes inequalities among people as a philosophical necessity and this is explained as a lawfulness of the development of human society, evolution and natural selection. On the other hand, elitist theories also defend inequalities. Gaetano Mosca's political formula is ideology - the moral justification of domination. Lords are more educated and prepared, with higher organic constituents. Max Weber says that one of the advantages of bureaucracy against common citizens is the more advanced education of bureaucrats compared to the others.

Sartre says that class relations automatically regulate the selection of practical knowledge technicians. In France, just a few workers belong to this social category because there are many obstacles in front of the worker's child hat prevent him/her from pursuing their university education. There is a large number of peasants in the working class who have become such as a result of the migration to the cities. Their children usually tend to get to lower administrative positions in the cities.

The scope of family incomes during education is also limited for the middle class. However, the children of this class enjoy better status than that of the workers' for life and studies. These children are aware of the fact that they belong to the middle class, the same as those who were born in medieval aristocracy. They tend to find themselves in that particular class. This, in essence, is the particularist ideology of the ruling class embedded in the population as a social Today social mobility is enabled through massive communication technologies; computerization, digitalization, satellite communications, optical cables and the Internet. The symbol of globalization is an open system it the social network, where everyone has access, even global terrorist organizations as are web messages and blogs of Al Qaeda. In the current stage of globalization it is counted the size of modems and the speed of internet. In the world there are created large markets supported by millions of investors from all around the world. This movement is at stake and has all the power in a "mouse" called electronic staid. They are essentially global financial centers like Val Street, Hong Kong, London, Frankfurt, etc. (Friedman,T., 2003, 24, 25).

If we refer to Jackson et al we will see that the "route to attaining educational qualifications of value in the labour market has two stages: the primary stage of reaching a minimum standard on school tests during the compulsory years of schooling and, conditional on that achievement, the secondary stage of choosing to make the transition to postcompulsory schooling". (Plewis I.,Barltey,M., 2014, pp 2)

By describing the life of people in suburban areas, colored Arab immigrants from former French colonies and people of social margins in general, unable to survive in the Marcusian-like dominated society, Pierre Bourdieu says that that kind of life can sorely be understood exactly. In order to precisely acknowledge what happens in this respect, one should live with people who are facing poverty, ignorance, conflicting situations and latency on daily basis. This world of contradictions is reproduced through new clients who come from different social strata and it is there that one can find the end of social disruption of tragical fates when the compromises of life can make it through and everyone is equal there ( Bourdieu,1999: 9).

While speaking about social aspects of stratification and readiness, Marx mainly determines them as a consequence of social division of labor and ownership over production tools, which is in fact class division.

Max Weber analyses in essence these relations when he talks about civic society. Even though he does not agree with Marx on the finding that the foundations of class division and economic equality confront the ownership of production tools and control over production and market, this theory is supplemented with other newer content and items.

\section{How much does globalization influence social mobility? Are there more opportunities for mobility in globalization?}

It is more than evident that technical-technological developments enable better and more achievable social mobility. Cell phones, email, online payments, etc., have increased superiority in production, utilization of free time and incredible easiness in communication among businesses, individuals, groups, professions, cultures, languages, etc. We mentioned above that industrial capitalism developed the transportation of goods, free market, financial capital, free movement of workforce and market, etc. Post-industrialism is further developing and improving these things both quantitatively and 
qualitatively: the emergence of the Internet, fast airplanes, cargo systems of goods transportation, containers, payments, work, distant purchasing, etc. provide new opportunities, unseen so far, related to communication among countries, cultures, peoples, remote regions, all across the world. Population migration stimulated greater movement of people from one place to another and this has caused the emergence of a combination of cultures through their social and cultural adaptation.

Immigrants play a crucial role in the globalization of countries; they contribute economically, socially, and culturally to both their homelands and their new countries of residence too.

Contemporary sociologists also talk about modern societies and their overall situation; they emphasize the peculiarity of the dynamic life in which changes are part of the everyday life, whereas information flow has made people become unsocial and addicted to computers, mass media, internet, market flow, excises, securities, etc.

It is well known that great profits from industrialization and economic development that was made possible by the bourgeoisie, represents the establishment of a society in which the middle class would dominate.

Post-industrial society in globalized countries seeks highly-qualified and educated workers such as managers, technicians, experts and other profiles. It is so not because Francis Bacon, Frederic Taylor, Fayol or even Francis Fukuyama have strived for these scientific profiles, but because of the fact such a society cannot exist today without having a real scientific and specialized elite. In the developed world, the social status is greatly determined by the level of education. Class divisions in the US can be said to mainly focus in distinctions in the field of education in the first place. There may seem not to be any obstacles in terms of one's progress in their education, however, at a highly developed level of education, inequality is still present in the system as a result of the unequal approach to education: the lack of education is the most secure way of judging and qualifying citizens as being trivial or second-hand citizens ( Fukuyama,2005: 19).

\section{Social mobility in education, inequalities}

Nowadays schools are undergoing constant transformations. Just half a century ago, in Western Balkans people from rural areas, in particular, wandered up and down just to get someone write a or read letter that had been addressed to them. Schools used to work with very few pupils and governments' intentions to include all 7-year-olds in schools have partially been realized. Today, education is the foundation of all activities in the community, and people, parents, pupils, etc. spend most of their time in activities related to school, education of their children, selection of schools, universities, enrolment fees, getting supplies such as books, etc.

In the globalized world, transformations and the idea of social progress are very closely related to knowledge and its distribution. John Fiske says that knowledge can never be neutral; it does not exist within an empirical interrelation or an objective connection with the real. Knowledge is power, and its circulation is part of the social distribution of that power.

Social mobility mandatorily creates inequalities. They are a constitutive part of the social statistics and they are created by the August Comtian-like style of social dynamics. Inequalities in education have been dealt with by sociology for a long time, especially in the field of social stratification, poverty issues and division of the society in classes.

Pluralism and liberal democracy, as vital parts of human rights, imply equal opportunities to all, regardless of their race, religion, ethnicity, social status, etc. However, social credibility, advancement in work or in a given social stratum, largely depends on appropriate qualifications, education and professional credibility acquired in institutions that have been accredited by law for that special purpose. This promotion has been preset and pre-announced and all citizens have equal chances to get informed and compete under the same circumstances in education, business, etc.

Scientific research on inequalities in education throughout human history, witness about phenomena that have been manifested as inequalities in two main fields:

1. Individual -

a. that has to do with individual differences among people

b. unequal individuals seen from the perspective of different social strata and social status of the family (family economy), parent education, etc.

2. Collective -

Dealing with racial, ethnic, religious, social discrimination manifested over minorities, marginal groups, etc.

In general, scientific literature takes into consideration three dominant factors of educational promotion and achievement, which are as follows: 
1. Individual abilities

2. Social status of the family

3. Parent education (including previous generations, their jobs, tradition, family achievements, etc.)

Education mandatorily has direct implications in social mobility. Therefore, these phenomena are manifested as movements from bottom up, between economic positions and employments, vertical and horizontal movements in the community. Mobility is also presented as a move or an individual's career within a generation (their career during their lives, work time) as well as among generations (the comparison of status, their movement with parents, etc).

The differences in the aspect of economic inequality among people do not solely depend on the control over production tools, but also on things that do not relate to them by any means, such as skills, professionalism, scientific background or diploma earned in educational institutions and which are too real for their high market prices. As a result, they earn a lot, get rich quickly and move upwards in their social gradation.

Education in post-communist societies should free people from prejudices, from the dogmas of collectivist spirit and from traditional authoritarian forms, says Francis Fukuyama. People should acquire habits of thinking about and seeking their own interest for as long as possible. Education makes people ask for more from themselves and from that, which causes the feeling of greater security in them, and as such, they want it to be accepted by other citizens and "valorized" by the state. Scientific studies, according to Fukuyama, show mainly a high correlation between peoples' statuses in society and their educational background.

In society, differences are not manifested only through genders, races, ethnicities, religions, but through generations too.

Table 1. Employed by net pay and gender, Macedonia, 2013

$\begin{array}{lcccc}\text { Gender } & \text { Total1) } & \text { Have not received pay2) } & \text { Unpaid family workers } & \text { Unknown } \\ \text { Total } & 678838 & 1968 & 60889 & 16136 \\ \text { Men } & 407531 & 1374 & 21912 & 10320 \\ \text { Women } & 271307 & (595) & 38977 & 5816 \\ & & & \\ \text { Total } & 100,0 & 0,3 & 9,0 & 2,4 \\ \text { Men } & 100,0 & 0,3 & 5,4 & 2,5 \\ \text { Women } & 100,0 & (0.2) & 14,4 & 2,1 \\ & & & 1000,0 \\ \text { Total } & 100,0 & 100,0 & 36,0 & 100,0 \\ \text { Men } & 60,0 & 69,8 & 64,0 & 36,1 \\ \text { Women } & 40,0 & (30.2) & \end{array}$

Source: Drzaven Zavod za statistika na Republika Makedonija, 2015

In Table 1 the social status of employees in Macedonia has been presented; as we can see, the number of employed women is half the less compared to that of men, i.e. 40,7531 males and 27,1307 females. This implies lower social mobility as well as inappropriate social status for women in Macedonia.

Table 2.. Net pay in denars in Macedonia 2013

$\begin{array}{cccccccccc}\text { Up to 5000 } & 5001- & 8001- & 10001- & 12001- & 16001- & 20001- & 25001- & 30001- & 40001 \text { and } \\ \text { Total 23 341 } & 8000 & 10000 & 12000 & 16000 & 20000 & 25000 & 30000 & 40000 & \text { more } \\ \text { Men 14 923 } & 24240 & 89350 & 109047 & 120140 & 96623 & 65030 & 26503 & 13759 & 9213 \\ \text { Women 8418 } & 22597 & 44772 & 68765 & 81884 & 61843 & 42728 & 17364 & 10155 & 7445 \\ \end{array}$

Source: Drzaven Zavod za statistika na Republika Makedonija, 2015 
Table 3. Structure by net pay in \%

\begin{tabular}{|l|c|c|c|c|c|c|c|c|c|}
\hline \multicolumn{10}{|c|}{ Structure by net pay in \% } \\
\hline Total:3,4 & $\mathbf{6 , 9}$ & $\mathbf{1 3 , 2}$ & $\mathbf{1 6 , 1}$ & $\mathbf{1 7 , 7}$ & $\mathbf{1 4 , 2}$ & $\mathbf{9 , 6}$ & $\mathbf{3 , 9}$ & $\mathbf{2 , 0}$ & $\mathbf{1 , 4}$ \\
\hline Men: 3,7 & 5,9 & 10,9 & 16,9 & 20,1 & 15,2 & 10,5 & 4,3 & 2,5 & 1,8 \\
\hline Women:3,1 & 8,3 & 16,5 & 14,8 & 14,1 & 12,8 & 8,2 & 3,4 & 1,3 & 0,7 \\
\hline
\end{tabular}

Source: Drzaven Zavod za statistika na Republika Makedonija, 2015

In Tables 2 and 3, we can see that salaries in Macedonia are the lowest in Europe. 23,341 female workers are currently paid about 5,000 MKD (82 Euros). The greatest number of employees, i.e. 109,047 are paid between 10,0001 and 12,000 MKD, which equals to 200 Euros. We can thus see that the largest portion of the population in Macedonia has low mobility and also a low social status.

\section{Trade on the Internet}

A typical example of social mobility and trade without border, time or bureaucratic limitations is EBay. Since 2002, it has been constantly developing and progressing.

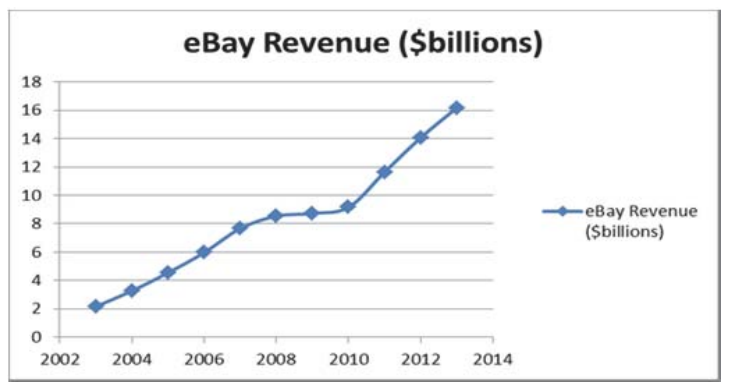

From the chart above, we can see the rapid changes in the profit of EBay, which earned about $\$ 9$ billion in 2010 to $\$ 16$ billion in 2014, with a tendency of improving even more. (https://www.google.com/search?q=ebay+worldwide+statistic, retrieved on 22.05.2015).

In Macedonia, online trading has also marked progress. More than 1 million Euros a month are spent by Macedonians for online shopping, based on the data from credit and other payment cards from the National Bank of Macedonia. From January to November 2014, Macedonians spent about 10.5 million Euros, compared to 2013, when they spent just 2.5 million Euros. Saving time as well as money, along with the large selection of products, is among the main reasons of online shopping.

Those who are familiar to global markets say that until now they have not had any kinds of problems - neither with the payments, nor with the purchased products.

Aleksandar Tasev, (2015) director of the e-market TC.mk, says for Alpha TV that the habits of Macedonians towards shopping have been changing, and the Internet, as one of the most accessible tools, especially for the young, is becoming the first shopping choice.

In Macedonia, you can find more than 300 online shops, which offer various different products and services.

The introduction of PayPal, the global system for on line payments, is another step forward for developing e-trade. This provides consumers security in their transactions.

According to the market experts, the increase of online shopping in the country is due to the readiness of the banking sector to offer such services, the large number of mobile telephony subscribers, as well as the change in citizens' habits towards the usage of technological solutions.

Otherwise, in order to develop online shopping in the country, the Government provided subsidies to several companies. The assistance included compilation of product catalogs, and the top five received web site maintenance and administration for a period of one year. 


\section{Conclusions}

- The development of social capitalism induced industrialization, education and urbanization of human society.

- There are various different definitions on social mobility but all of the scholars more or less agree that it is a crucial part of life, work and social status of the individual, especially in globalized societies.

- Education and the level of achievements in it enable greater vertical mobility from bottom up.

- Neo-liberalism opens up new ways of worldwide mobility but also increases inequalities among individuals, groups, regions, etc.

- In Macedonia there are low salaries and even lower social mobility. E-bay enables a comfortable form of intercultural communication, by re-dimensioning time, space, and distance in an unimaginable way in just two decades from its emergence.

\section{References}

Burdieu,P. (1999) La misere du monde, Seuil, Paris

Bartlet,W. ( 2010). People Centered Analyses, Quality in Social Services,UEJL, Tetove

Goldthorpe,H.J.( 1993).Class Analysis and the Reorientation of Class Theory: The Case of Persisting Differentials in Educational Attainment

Giddens, A. (1997). Sociologjia, Cabej, Tirane

Fridman,L.T. (2008) Leksusot I maslinovoto drvo, Agora,Skopje

Hughes, M., Kroehler, J. C., Vander Zanden, J. (2003).Sociology, Social Mobility, McGraw-Hill, $5^{\text {th }}$ edition.

The British Journal of Sociology (1993).Vol. 47, No. 3, Special Issue for Lockwood, pp. 481-505

Marx K., Engels,F., Manifesto of the Communist Party, Renaissance Prishtina, 1978, pp, 6-7.

Plewis I.,Bartley,M., ( 1914)Intra-generational social mobility and educational qualifications, Research in Social Stratification and Mobility Open Access funded by Economic and Social Research Council, Vol. 36 pp 2.

Fukujama,F. 19) (2005).The end of History and the Last Man, Paperback: 464 ,Publisher: Free Press; Reissue edition

Drucker,P.(1995).Postkapitlisticko drustvo,Privredni Pregled, Grmec,Beograd, pp 12.

Steger,M.(2003,22-23). Globalization. A very short Introduction,Oxford University- Press

Анкета за работната сила, 2013, (2014). Државен завод за статистика на Македонија, Скопје,

Sartre, P.J. (1988) Situatat, Rilindja, Prishtine

\section{Electronics sources:}

https://www.google.com/search?q=ebay+worldwide+statistics\&espv=2\&biw=1366\&bih=643\&source=In, retrieved in 22.05.2015 http://www.alfa.mk/News.aspx?ID=89985\#.VWAyXE- retrieved in 22.05.2015 